\title{
KONTROVERSI MISS WORLD 2013 DI MEDIA
}

\author{
Yudin Taqyudin dan Rulli Nasrullah
}

\begin{abstract}
Abstrak
Berita tidak sekadar merupakan realitas dari peristiwa yang ada di lapangan dan dilaporkan oleh wartawan dan media. Dalam pandangan teori framing dijelaskan bahwa apa yang disajikan di media massa telah melalui proses seleksi terhadap data serta fakta yang dilakukan sesuai dengan ideologi media tersebut. Kontrovesi penyelenggaraan Miss World 2013 yang diberitakan oleh Republika merupakan objek penelitian dalam tulisan ini yang dianalisis dengan menggunakan perangkat framing dari Zhongdang Pan dan Gerald M. Kosicki. Hasilnya menunjukkan bahwa teks berita bisa menunjukkan ideologi apa yang ada di media tersebut.
\end{abstract}

Kata Kunci: miss world, framing, media massa, Islam

\section{A. Pendahuluan}

Berita seputar penyelenggaraan kontes Miss World 2013 yang akan diselenggarakan di Indonesia cukup menarik perhatian, terutama ketika berita tersebut disajikan sebuah media massa yang memiliki kecenderungan ideologi agama. Sebagai negara berpenduduk mayoritas beragama Islam, kontes tersebut tentu lebih banyak menuai kontoversi. Bahkan bila dihadapkan dengan budaya ketimuran, juga akan menghadapi perbedaan. Media massa yang berideologi agama pun akan menyajikan berita itu berdasarkan perspektifnya. Ini terbukti dengan pemberitaan gelaran Miss World yang diberitakan Republika secara intensif.

$$
\text { Kebanyakan khalayak }
$$

menganggap bahwa apa yang diberitakan media massa merupakan realita yang terjadi atau cermin dari realitas yang ada di lapangan. Media massa dianggap hanya sebagai medium yang memberitakan peristiwa dengan apa adanya tanpa adanya motif atau kepentingan di dalamnya. Akan tetapi, pada dasarnya media adalah saluran yang dimanfaatkan untuk mengendalikan arah dan 
memberikan dorongan terhadap perubahan sosial bahkan oleh pelaku media itu sendiri entah untuk karena dasar eonomi, sosial, politik, dan sebagainya (lihat McQuail, 1996:35; Moscow, 1996/2009; Albarran, 1996).

Framing digunakan untuk melihat bagaimana media membingkai sebuah peristiwa (Kriyantono, 2006:251-252). Dalam melakukan pembingkaian tentunya secara teks media akan memilih sudut pandang mana yang ingin digunakan sekaligus ditampilkan terhadap realitas di lapangan yang menjadi realitas media. Karena itu ketika melakukan framing ada yang terbuang dan ada yang tampak dalam teks yang disajikan (lihat Birowo (ed.), 2004).

Kontroversi yang mengiringi rencana penyelenggaraan kontes Miss World 2013 di Indonesia itu merupakan realitas yang bisa diberitakan oleh media. Penolakan demi penolakan mulai dari organisasi keagamaan, organisasi kemahasiswaan, sampai pada individu-individu muncul seiring persiapan perhelatan dunia itu di Bali. Berdasarkan realitas ini tulisan ini mengupas bagaimana media mengangkat kontrroversi tersebut. Analisis framing secara sederhana dapat digambarkan sebagai analisis untuk mengetahui bagaimana suatu peristiwa atau realitas dibingkai oleh media (Eriyanto, 2005:3). Di sini realitas sosial dimaknai dan dikonstruksi dengan makna tertentu, peristiwa dipahami dengan bentukan tertentu. Melalui penelitian ini, peneliti merasa perlu untuk mengkaji lebih lanjut karakter pemberitaan tentang penyelenggaraan Miss World 2013 di Indonesia pada harian Republika, dilihat dari proses pembingkaian masalah pada berita-berita yang disampaikan.

\section{B. Metodologi}

Dengan analisis data maka penelitian ini menampilkan temuan tentang letak perbedaan teks berita yang disajikan dan menafsirkan hasil temuan berdasarkan model analisis framing yang diterapkan, yakni model Zhongdang Pan dan Gerald M. Kosicki (lihat Eriyanto, 2005). Model ini membagi struktur analisis menjadi empat bagian, yakni unsur sintaksis untuk melihat cara wartawan menyusun berita mulai dari penempatan headline merupakan berita yang dijadikan topik utama oleh media, penulisan teras berita, latar informasi, kutipan, sampai pada pemilihan sumber. Kemudian unsur skrip di mana unsur ini melihat 
bagaimana cara wartawan mengisahkan fakta. Struktur skrip memfokuskan perangkat framing pada kelengkapan berita: What (apa), When (kapan), Who (siapa), Where (di mana), Why (mengapa), dan How (bagaimana). Unsur tematik adalah cara wartawan menulis fakta. Struktur tematik mempunyai perangkat framing antara lain maksud dan hubungan kalimat, koherensi, hingga detail dan bentuk kalimat. Terakhir adalah unsur retoris yakni untuk melihat bagaimana cara wartawan menekankan fakta. Struktur retoris mempunyai perangkat framing seperti leksikon atau pilihan kata, grafis dan metafora. Ke empat unsur tersebut digamabrkan berikut ini:

\section{Tabel 1}

Perangkat Framing Zhongdang Pan dan Gerald M. Kosicki

\begin{tabular}{|l|l|l|}
\hline STRUKTUR & $\begin{array}{c}\text { PERANGKAT } \\
\text { FRAMING }\end{array}$ & $\begin{array}{c}\text { UNIT } \\
\text { YANG } \\
\text { DIAMATI }\end{array}$ \\
\hline $\begin{array}{l}\text { Sintaksis } \\
\text { (Cara } \\
\text { wartawan } \\
\text { menyusun } \\
\text { fakta) }\end{array}$ & $\begin{array}{c}\text { 1.Skema } \\
\text { berita }\end{array}$ & $\begin{array}{l}\text { Headline, } \\
\text { lead, latar } \\
\text { informasi, } \\
\text { kutipan, } \\
\text { sumber, } \\
\text { pernyataan, } \\
\text { penutup. }\end{array}$ \\
\hline $\begin{array}{l}\text { Skrip } \\
\text { (Cara } \\
\text { wartawan } \\
\text { mengisahkan }\end{array}$ & Berita & $5 \mathrm{~W}+1 \mathrm{H}$ \\
\hline
\end{tabular}

\begin{tabular}{|c|c|c|}
\hline fakta) & & \\
\hline $\begin{array}{l}\text { Tematik } \\
\text { (Cara } \\
\text { wartawan } \\
\text { menulis } \\
\text { fakta) }\end{array}$ & $\begin{array}{l}\text { 3. Detail } \\
\text { 4. Koherensi } \\
\text { 5. Bentuk } \\
\quad \text { kalimat } \\
\text { 6. Kata ganti }\end{array}$ & $\begin{array}{l}\text { Paragraf, } \\
\text { proposisi, } \\
\text { kalimat } \\
\text { hubungan } \\
\text { antar } \\
\text { kalimat }\end{array}$ \\
\hline $\begin{array}{l}\text { Retoris } \\
\text { (Cara } \\
\text { wartawan } \\
\text { menekankan } \\
\text { fakta) }\end{array}$ & $\begin{array}{l}\text { 7. Leksikon } \\
\text { 8. Grafis } \\
\text { 9. Metafora }\end{array}$ & $\begin{array}{l}\text { Kata, idiom, } \\
\text { gambar/ } \\
\text { foto, grafik }\end{array}$ \\
\hline
\end{tabular}

\section{Hasil Penelitian}

Harian Republika pada 13 April 2013 halaman 11 mengangkat berita tentang adanya alasan mendasar kenapa Miss World memicu penolakan. Republika kembali mengangkat bahasan tentang penyelenggaraan Miss World. Meski di halaman belakang, berita dengan judul 'Esensi Miss World Picu Penolakan', masih berisi kritik dan upaya penggiringan opini seakan acara tersebut mesti ditolak. Dalam berita itu disebutkan bahwa ajang Miss World ditolak karena esensinya lebih banyak mengabaikan sisi bakat dan kemampuan perempuan. Apalagi penilaian dalam kontes seperti itu sebatas kecantikan, kecerdasan, atau bahkan bentuk tubuh (lihat Gambar 1). 
Republika - 13/04/2013

Esensi Miss World Picu Penolakan

- Agus Raharjo

Pembelaan panitia dengan menjanjikan kontes ini tidak menampilkan pakaian bikini dinila

\section{JAKARTA - Penolaka} rhadap rencana akan dihelatnya kontes kecantikan Miss
World di Bogor terus berlant. Persoalan utama yang menjadi dasar penolakaan in
dalah adanya perbedaa ang perempuan. Ajang itu ditolak karena
esensinya lebih banyak engabaikan sisi bakat dan kemampuan perempuan. Apa eperti itu sebatas kecantikar uk tubuh.
Manurut Ketua PP MuManurut Ketua PP Muontes seperti itu tidak panta dilakukan di tengah masyaraon apa pun bentuknya yans menilai perempuan tidak layak an soal bikini saja, tapi mepantas," kata Yunahar, Juma 2/4). utsertaan Indonesia dalam jang seperti ini menjadi maut dianggapnya sebagai tanegatif sudah masuk jauh nesia, menurut dia, tidak me-
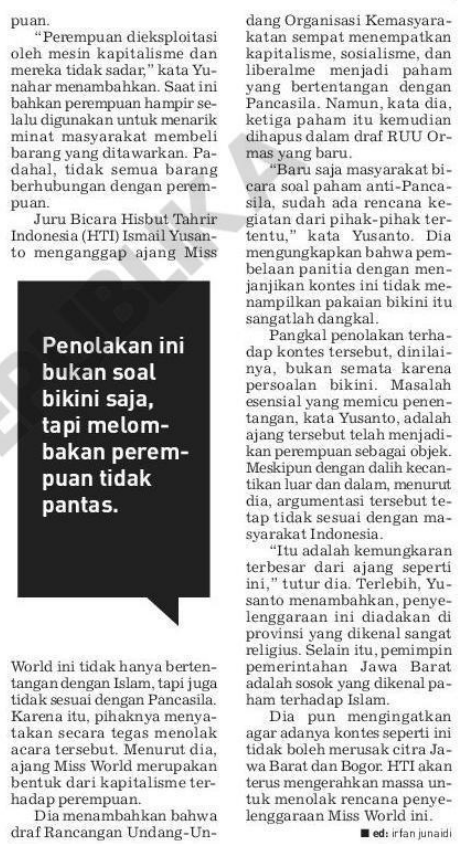

Berikut adalah ulasan tentang framing yang digunakan Republika:

\section{Sintaksis}

\section{a. Headline}

Esensi Miss World Picu Penolakan

Secara sintaksis, berita tersebut berisi alasan mendasar yang menjadi pemicu penolakan terhadap penyelenggaraan Miss World. Judul tersebut merupakan kutipan dari pernyataan Ketua PP Muhammadiyah Yunahar llyas yang menilai esensi kontes kecantikan itu adalah melombakan perempuan dan kontes tersebut sebagai bentuk eksploitasi

oleh

mesin

kapitalisme.

\section{b. Lead}

Dari sisi sintaksis peneliti menilai bahwa berita tersebut hendak menyampaikan tentang masih terjadinya penolakan terhadap rencana pelaksanaan Miss World di Indonesia. Ini terlihat pada paragraf berikut: JAKARTA -- Penolakan terhadap rencana akan dihelatnya kontes kecantikan Miss World di Bogor terus berlanjut. Persoalan utama yang menjadi dasar penolakan ini adalah adanya perbedaan standar bagaimana memandang perempuan.

Melalui lead di atas peneliti melihat bahwa wartawan harian Republika menegaskan kembali bahwa pelaksanaan Miss World di Indonesia masih menuai penolakan. Bahkan pada berita di atas ditegaskan mengenai alas an mendasar penolakan tersebut, yakni adanya perbedaan standar bagaimana memandang perempuan.

Lead yang dipakai pada pemberitaan ini termasuk dalam jenis statement lead (teras berita pernyataan). Seperti yang 
tertulis, yaitu pernyataan adanya penolakan terhadap rencana penyelenggaraan Miss World. Adapun berdasarkan $5 \mathrm{~W}+1 \mathrm{H}$ nya menggunakan lead what yang menonjolkan peristiwa yang sedang dibahas.

\section{c. Latar}

Dari wacana latar
informasinya
menemukan teks berita yang
berbunyi:

Ajang itu ditolak karena esensinya lebih banyak mengabaikan sisi bakat dan kemampuan perempuan. Apalagi penilaian dalam kontes seperti itu sebatas kecantikan, kecerdasan, atau bahkan bentuk tubuh..... Menurut Ketua PP Muhammadiyah Yunahar llyas, kontes seperti itu tidak pantas dilakukan di tengah masyarakat Muslim. Kontes kecantikan apa pun bentuknya yang menilai perempuan tidak layak dilakukan. "Penolakan ini bukan soal bikini saja, tapi melombakan perempuan tidak pantas," kata Yunahar, Jumat (12/4).

Dari kutipan berita tersebut penekanan yang dijadikan latar informasi oleh harian Republika adalah alasan kenapa penyelenggaraan Miss World di Indonesia menuai penolakan. Alasan penolakan itu karena esensi dari pelaksanaan Miss World dinilai lebih banyak mengabaikan sisi bakat dan kemampuan perempuan. Selain itu, untuk mendukung latar tersebut, dikutip pula pernyataan Ketua PP Muhammadiyah Yunahar llyas yang menyebutkan bahwa kontes seperti itu tidak pantas di tengah masyarakat Muslim.

Harian Republika memaknai pernyataan Ketua PP Muhammadiyah Yunahar Ilyas itu sebagai alasan mendasar kenapa penyelenggaraan Miss World di Indonesia menuai penolakan. Latar informasi ini pula selaras dengan judul yang diangkat. Pada tubuh berita tersebut peneliti menemukan kalimat berita yang bertuliskan:

Pangkal penolakan terhadap kontes tersebut, dinilainya, bukan semata karena persoalan bikini. Masalah esensial yang memicu penentangan tersebut telah menjadikan perempuan sebagai objek. Meskipun dengan 
dalih kecantikan luar dan dalam,

menurut dia, argumentasi tersebut tetap tidak sesuai dengan masyarakat Indonesia.

Penggalan berita di atas dimaknai harian Republika sebagai upaya penegasan pernyataan sebelumnya yang menilai bahwa inti dari alasan penolakan terhadap penyelenggaraan Miss World yang menjadikan perempuan sebagai objek penilaian. Paragraf tersebut merupakan pernyataan dari kutipan juru bicara Hisbut Tahrir Indonesia (HTI) Ismail Yusanto.

Bila dtelusuri lebih jauh pada penggalan berita ini, ada paya untuk menyudutkan penyelenggaraan Miss World di Indonesia dengan berbagai alasan, di antaranya adalah karena kontes kecantikan sejagad itu lebih menilai perempuan sebagai objek yang mengutamakan dari sisi kecantikan serta tidak sesuainya dengan tradisi masyarakat Indonesia.

\section{d. Kutipan}

Untuk melengkapi berita yang menampakkan penolakan terhadap pernyelenggaraan Miss World di Indonesia, harian Republika menyusun berita ini dengan mengutip pernyataan Ketua PP Muhammadiyah Yunahar llyas yang tertulis:

"Penolakan ini bukan soal bikini saja, tapi melombakan perempuan tidak pantas," kata Yunahar, Jumat (12/4).... "Perempuan dieksploitasi oleh mesin kapitalisme dan mereka tidak sadar," kata Yunahar menambahkan.

Selain itu adapula kutipan langsung dari Juru Bicara Hisbut Tahrir Indonesia (HTI) Ismail Yusanto yang tertulis:

"Itu adalah kemungkaran terbesar dari ajang seperti ini," tutur dia. Terlebih, Yusanto menambahkan,

penyelenggaraan ini diadakan di provinsi yang dikenal sangat religius. Selain itu, pemimpin pemerintahan Jawa Barat adalah sosok yang dikenal paham terhadap Islam.

Penggalan berita tersebut memperlihatkan bahwa dua ormas, yakni Muhammadiyah dan HTI menolak 
penyelenggaraan Miss World di Indonesia karena alasan mendasar, yaitu karena kontes sejagad tersebut menjadikan perempuan sebagai objek penilaian.

\section{e. Pernyataan}

Untuk mmelihat bagaimana haran Republika memorsikan pernyataan dari narasumber, bisa dilihat pada bentuk berita yang ditulis sebagai berikut:

Menurut Ketua PP Muhammadiyah Yunahar llyas, kontes seperti itu tidak pantas dilakukan di tengah masyarakat Muslim. Kontes kecantikan apa pun bentuknya yang menilai perempuan tidak layak dilakukan..... Juru Bicara Hisbut Tahrir Indonesia (HTI) Ismail Yusanto menganggap ajang Miss World ini tidak hanya bertentangan dengan Islam, tapi juga tidak sesuai dengan Pancasila.

Dari kutipan pernyataan dalam teks berita peneliti mengambil sebah kesimpulan bahwa pernyataan itu menunjukkan adanya penolakan dari Ketua PP Muhammadiyah
Yunahar llyas dan Juru Bicara Hisbut Tahrir yang menyatakan bahwa Miss World bukan sekedar penampilan fisik perempuan, melainkan esensi kontes tersebut yang memperlombakan perempuan.

\section{Skrip}

Dari wacana analisis skripnya sudah cukup jelas pemaparan dari wartawan perihal kelengkapan $5 \mathrm{~W}+1 \mathrm{H}$. Sehingga akan membuat pembaca merasa menemukan kelengkapan informasi dalam memahami berita tersebut.

\section{Tematik}

\section{a. Detail}

Dilihat dai frame tematiknya peneliti mengamati dari elemen wacana detail dan maksud kalmat serta koherensi antar paragraph dari detal berita tersebut seperti yang terlihat pada teks berikut ini:

Menurut Ketua PP
Muhammadiyah Yunahar llyas,
kontes seperti itu tidak pantas
dilakukan di tengah masyarakat
Muslim. Kontes kecantikan apa
pun bentuknya yang menilai
perempuan tidak layak
dilakukan. "Penolakan ini bukan


soal bikini saja, tapi melombakan perempuan tidak pantas," kata Yunahar, Jumat (12/4).

Pada petikan di atas terdapat detail penjelasan mendasar dari Ketua PP Muhammadiyah Yunahar llyas tentang alasan penolakan Miss World. Alasan itu berupa adanya perbedaan pandangan terhadap perempuan dalam kontes itu.

\section{b. Koherensi}

Wartawan melakukan penekanan dan pemaknaan terhadap pernyataan dua narasumber yang menolak Miss World di Indonesia. Penolakan tersebut bukan karena pakaian yang dipakai para peserta, melainkan pada esensi kegiatan yang menjadikan perempuan sebagai objek kontes. Hal itu terlihat pada paragraf berikut ini:

Pangkal penolakan terhadap kontes tersebut, dinilainya, bukan semata karena persoalan bikini. Masalah esensial yang memicu penentangan tersebut telah menjadikan perempuan sebagai objek. Meskipun dengan dalih kencantikan luar dan dalam, menurut dia, argumentasi tersebut tetap tidak sesuai dengan masyarakat Indonesia.

Pada petikan tersebut harian Republika melakukan penekanan dan pemaknaan secara tegas terhadap penyelenggaraan Miss World di Indonesia, yakni kontes sejagad itu ditolak bukan karena persoalan bikini, melainkan masalah esensialnya adalah karena perempuan sebagai objeknya.

\section{c. Bentuk Kalimat}

Penulisan kalimat dalam berita ini bersifat deduktif, di mana hal yang utama diuraikan pada paragraf yang disusul uraian pelengkap selanjutnya. Dalam berita ini pula, wartawan menggunakan kalimat aktif dan pasif, yakni dengan pemakaian awalan me- dan di- yang cukup berimbang.

\section{Retoris}

\section{a. Leksikon}

Leksikon menandakan bagaimana seseorang melakukan pemilihan kata atas berbagai kemungkinan kata yang tersedia. Dari analisis retorisnya 
peneliti melihat yang banyak digunakan sebagai retorikanya adalah pada leksikon yang terdapat pada teks berita. Dalam berita ini, wartawan masih menonjolkan kata 'penolakan' sebagai bentuk penegasan judul berita untuk menunjukkan bahwa penyelenggaraan Miss World di Indonesia masih memicu penolakan. Adapula beberapa kata yang dipilih wartawan sebagai penegas, yaitu standar, esensi, eksploitasi, kapitalisme, dan kemungkaran.

\section{b. Idiom}

Idiom adalah bentuk bahasa berupa gabungan kata yang makna katanya tidak dijabarkan dari mana unsure gabungan dalam wacana pesan tidak hanya disampaikan lewat teks atau bahasa formal, tetapi juga kiasan, dan ungkapan yang dimaksudkan sebagai ornamen atau bumbu yang dapat dipakai untuk memperkuat pesan utama. Adapun unsur idiom yang ditemukan dalam berita ini adalah 'Anti-Pancasila' yang berarti menolak paham Pancasila.
Tabel 2

Framing Edisi 13 April 2013

"Esensi Miss World Picu

Penolakan"

\begin{tabular}{|c|c|}
\hline \multicolumn{2}{|c|}{ Frame Esensi Miss World Picu Penolakan } \\
\hline Struktur & Variabel \\
\hline Sintaksis & 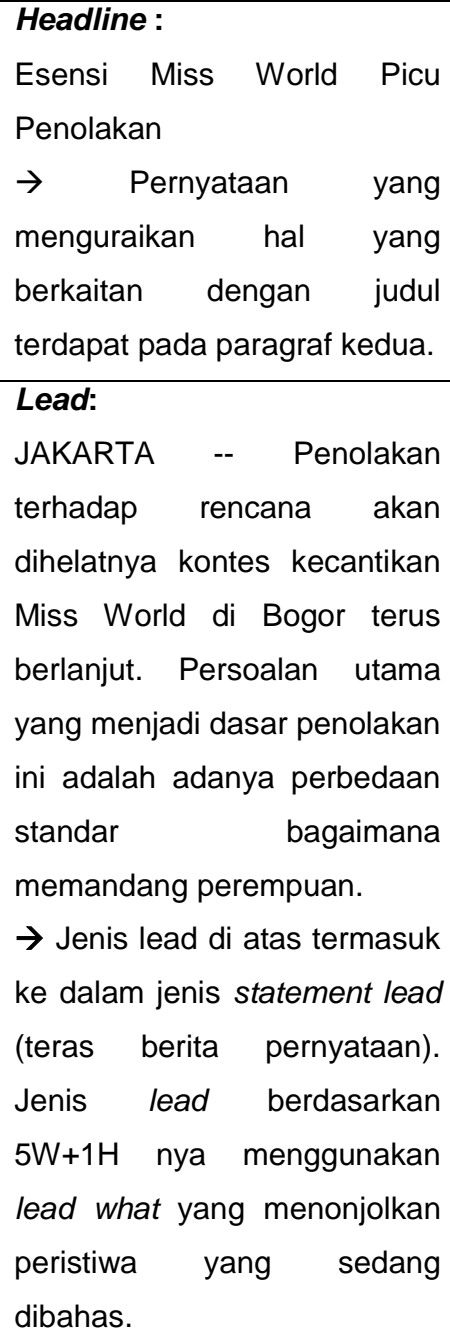 \\
\hline & $\begin{array}{l}\text { Latar Informasi: } \\
\text { Ajang itu ditolak karena } \\
\text { esensinya lebih banyak } \\
\text { mengabaikan sisi bakat dan } \\
\text { kemampuan perempuan. } \\
\text { Apalagi penilaian dalam } \\
\text { kontes seperti itu sebatas } \\
\text { kecantikan, kecerdasan, atau } \\
\text { bahkan bentuk tubuh. } \\
\rightarrow \text { Latar informasi yang }\end{array}$ \\
\hline
\end{tabular}




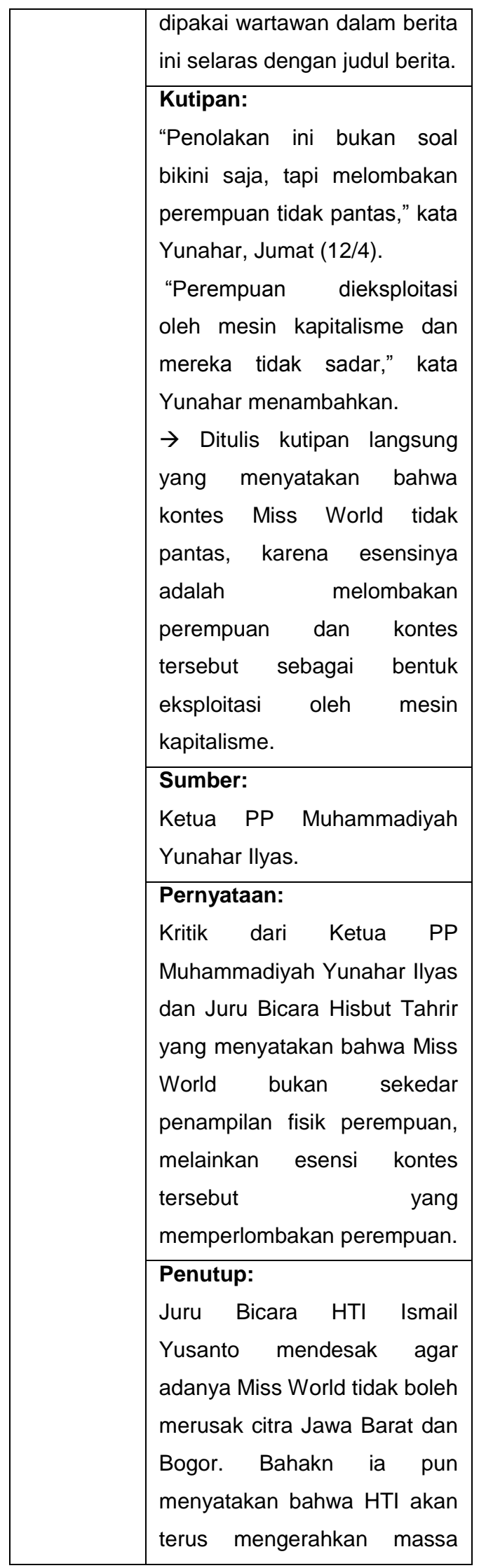

\begin{tabular}{|c|c|}
\hline & $\begin{array}{l}\text { untuk menolak rencana } \\
\text { penyelenggaraan Miss World } \\
\text { ini. } \\
\rightarrow \text { Penutup ini sebagai } \\
\text { konsekuensi penolakan HTI } \\
\text { terhadap penyelenggaraan } \\
\text { Miss World. }\end{array}$ \\
\hline \multicolumn{2}{|c|}{$\begin{array}{l}\text { Pada berita ini, wartawan menyusun fakta } \\
\text { dengan mengedepankan fakta penolakan } \\
\text { oleh penyelenggaraan Miss World. } \\
\text { Selanjutnya disampaikan fakta-fakta berupa } \\
\text { kutipan dan pernyataan yang menunjukkan } \\
\text { bahwa esensi Miss World memicu } \\
\text { penolakan. }\end{array}$} \\
\hline \multirow[t]{6}{*}{ Skrip } & $\begin{array}{l}\text { Who: } \\
\text { Ketua PP Muhammadiyah } \\
\text { Yunahar llyas, Juru Bicara Hisbut } \\
\text { Tahrir Ismail Yusanto. }\end{array}$ \\
\hline & $\begin{array}{l}\text { What: } \\
\text { Esensi Miss World picu } \\
\text { penolakan. }\end{array}$ \\
\hline & $\begin{array}{l}\text { When: } \\
\text { Jum'at, } 12 \text { April } 2013 \text { (waktu } \\
\text { kutipan Yunahar llyas) }\end{array}$ \\
\hline & $\begin{array}{l}\text { Where: } \\
\text { Bogor, Jawa Barat (lokasi } \\
\text { pelaksanaan Miss World) }\end{array}$ \\
\hline & $\begin{array}{l}\text { Why: } \\
\text { Persoalan utama yang menjadi } \\
\text { dasar penolakan ini adalah } \\
\text { adanya perbedaan standar } \\
\text { bagaimana memandang } \\
\text { perempuan. }\end{array}$ \\
\hline & $\begin{array}{l}\text { How: } \\
\text { Ajang itu ditolak karena } \\
\text { esensinya lebih banyak } \\
\text { mengabaikan sisi bakat dan } \\
\text { kemampuan perempuan. Apalagi } \\
\text { penilaian dalam kontes seperti itu } \\
\text { sebatas kecantikan, kecerdasan, } \\
\text { atau bahkan bentuk tubuh. }\end{array}$ \\
\hline
\end{tabular}




\begin{tabular}{|c|c|}
\hline \multicolumn{2}{|c|}{$\begin{array}{l}\text { Cara wartawan dalam mengisahkan fakta } \\
\text { memakai seluruh elemen } 5 \mathrm{~W}+1 \mathrm{H} \text {, agar } \\
\text { terlihat netral dan menjawab pertanyaan } \\
\text { pembaca terhadap semua elemen itu. }\end{array}$} \\
\hline \multirow[t]{3}{*}{ Tematik } & $\begin{array}{l}\text { Detail: } \\
\text { Terdapat penjelasan mendasar } \\
\text { dari Ketua PP Muhammadiyah } \\
\text { Yunahar llyas tentang alasan } \\
\text { penolakan Miss World. Alasan itu } \\
\text { berupa adanya perbedaan } \\
\text { pandangan terhadap perempuan } \\
\text { dalam kontes itu. }\end{array}$ \\
\hline & $\begin{array}{l}\text { Koherensi: } \\
\text { Wartawan melakukan penekanan } \\
\text { dan pemaknaan terhadap } \\
\text { pernyataan dua narasumber } \\
\text { yang menolak Miss World di } \\
\text { Indonesia. Penolakan tersebut } \\
\text { bukan karena pakaian yang } \\
\text { dipakai para peserta, melainkan } \\
\text { pada esensi kegiatan yang } \\
\text { menjadikan perempuan sebagai } \\
\text { objek kontes. }\end{array}$ \\
\hline & $\begin{array}{l}\text { Bentuk Kalimat: } \\
\text { Penulisan kalimat dalam berita } \\
\text { ini bersifat deduktif, di mana hal } \\
\text { yang utama diuraikan pada awal } \\
\text { paragraf dan disusul dengan } \\
\text { uraian sebagai pelengkap } \\
\text { selanjutnya. Dalam berita ini } \\
\text { pula, wartawan menggunakan } \\
\text { kalimat aktif dan pasif, yakni } \\
\text { dengan pemakaian awalan me- } \\
\text { dan di- yang cukup berimbang. }\end{array}$ \\
\hline \multicolumn{2}{|c|}{$\begin{array}{l}\text { (1) Penolakan terhadap Miss World terus } \\
\text { berlanjut. } \\
\text { (2) Perbedaan terhadap standar } \\
\text { bagaimana memandang perempuan } \\
\text { sebagai objek kontes menjadi dasar } \\
\text { penolakan. }\end{array}$} \\
\hline Retoris & \\
\hline
\end{tabular}

\begin{tabular}{|c|c|}
\hline & $\begin{array}{l}\text { Dalam berita ini, wartawan masih } \\
\text { menonjolkan kata 'penolakan' } \\
\text { sebagai bentuk penegasan judul } \\
\text { berita. Adapula beberapa kata } \\
\text { yang dipilih wartawan sebagai } \\
\text { penegas, yaitu standar, esensi, } \\
\text { eksploitasi, kapitalisme, dan } \\
\text { kemungkaran. }\end{array}$ \\
\hline & $\begin{array}{l}\text { Idiom: } \\
\text { Anti-Pancasila. } \\
\rightarrow \quad \text { Perilaku } \\
\text { bertolakbelakang } \\
\text { Pancasila. }\end{array}$ \\
\hline & Foto: - \\
\hline & Grafis: - \\
\hline $\begin{array}{l}\text { Penggunaa } \\
\text { merupakan } \\
\text { menekanka } \\
\text { penolakan } \\
\text { Indonesia. }\end{array}$ & $\begin{array}{l}\text { an kata 'penolakan' dan 'esensi' } \\
\text { cara wartawan untuk } \\
\text { terhadap Miss World di }\end{array}$ \\
\hline
\end{tabular}

\section{Kesimpulan}

Ideologi berhubungan dengan konsepsi atau posisi seseorang dalam menafsirkan realitas. Melalui level ideologi kita akan melihat bagaimana arah pemberitaan sebuah media, seperti halnya Republika ketika memberitakan rencana penyelenggaraan Miss World di Indonesia. Ketika harian itu menyajikan berita tersebut, hasil akhirnya adalah adanya bagian tertentu dari realitas yang lebih menonjol dan lebih mudah dikenal. Akibatnya, khalayak lebih mudah mengingat aspek-aspek terntentu yang 
disajikan secara menonjol oleh media (lihat Sudibyo, 2001: 12).

Melalui analisis framing, terlihat bagaimana kecenderungan sebuah media dalam memberitakan sebuah peristiwa. Berita yang disajikan harian Republika merepresentasikan kritik terhadap kontes tersebut. Cara ini dibangun antara lain dengan mengutip beberapa narasumber yang cenderung menolak. Meskipun disertai dengan narasumber lain yang berlainan pandangan, namun dari seluruh berita yang disajikan harian Republika menegaskan bahwa sejatinya harian tersebut berupaya mengkritik sekaligus memberikan saran sebagai alternatif untuk kegiatan tersebut.

\section{E. Daftar Pustaka}

Albarran, Alan B. (1996). Media Economics. lowa: lowa State University Press.

Birowo, Antonius (ed.). (2004). Metode

Penelitian Komunikasi. Jogjakarta:Gitanydali.

Eriyanto. (2005). Analisis Framing; Konstruksi, Ideologi, dan Politik Media. Yogyakarta: LKiS Yogyakarta.

Kriyantono, Rachmat. (2006). Riset Komunikasi. Jakarta: Kencana.
McQuail, Denis. (1996). Teori Komunikasi Massa: Suatu Pengantar. Jakarta: Erlangga.

Mosco, Vincent. (1996/2009). The Political Economy of Communication. London: Sage Publication.

Sudibyo, Agus. (2001). Politik Media dan Pertarungan Wacana. Yogyakarta: LKiS. 